\title{
Construction of Regional Low Carbon Innovation System
}

\author{
Yang Wang ${ }^{1, a}$, Bo Zhao ${ }^{1, b}$, Kui Chen ${ }^{2, c}$ \\ ${ }^{1}$ Harbin University of Science and Technology, Harbin 150000, China; \\ ${ }^{2}$ Xiamen University, Fujian 315200, China. \\ a974071140@qq.com, b1064191782@qq.com, ’m14745169144_1@163.com
}

\begin{abstract}
Key words: Regional low carbon innovation system; Innovative environment; Innovative resources; System construction
\end{abstract}

\begin{abstract}
Under the background of global warming, this paper constructs a low carbon innovation system from the research perspective of China's regional. The research framework of the system is based on the theory of regional low-carbon innovation system to interpret the concept of regional low-carbon innovation system, clears its function, analysis its resources; The environment are described; Then, study the purpose and significance of regional low-carbon innovation system, and put forward suggestions for the development of low-carbon innovation system, promoting the sustainable development of economy and ecology.
\end{abstract}

\section{Introduction}

The emergence of the global warming problem has made the world begin to think about how to solve the problem of the economic development of human society and the harmonious coexistence of the ecological environment. The convening of the Copenhagen Climate Change Conference (2009) shows that the concept of "low carbon economy", which is low energy consumption, low pollution and low emission. Paris climate summit (2015) is also on strengthening the global climate change issues to explore, to reach a consensus control warming.

The core content of the development of low carbon economy is technology innovation. In 2003, the UK energy white paper released "our energy future: creating a low carbon economy, strengthen the elaboration of low-carbon innovation, emphasizing the influence of the transition to a low carbon economy [1]. China is in the stage of resource consumption in the economic development, and the establishment of a new low carbon development model is the fundamental way to get rid of energy dependence and improve energy efficiency.

The party's "the 17th National Congress" put forward the major tasks of the national innovation system strategy about construct the "resource-saving and environment-friendly" of the "two type" society. To pay attention to regional economic development and to build a perfect regional innovation system plays an important role in China's participation in international competition. Especially in the 2008 World Wildlife Fund will be launched the "China's low-carbon urban development project", the provinces and cities of China gradually joined the ranks of "low carbon", try best to devote into the low carbon industrial revolution.

\section{Relevant theoretical basis}

Ecology economic and circular economic theory. The concept of eco economics was first proposed by the American economist Kenneth Boulding. The theory combines the cross theory of 
the ecological law and economic law, and strive to promote the development of human economy on the regulation and protection of the ecological environment, reduce environmental pollution and waste of resources.

Circular economy emphasizes material resources intensive utilization and recycling. In manufacturing process and the transformation process, improve the efficiency of resource use and do most possible to reduce energy waste with strengthening the clean energy using as the main means, emphasizing on the waste reuse and suppressing environmental damage and deterioration of ecological environment, so as to realize the sustainable and harmonious development of the economic society and the natural environment.

Theory of low carbon economy. Low carbon economy is a kind of sustainable economic development mode, and it also coordinates the relationship between economic development and resources and environment carrying capacity. Special emphasis on the various factors in energy-environment-economy system coordinated development, achieve the both of economic development and energy saving and emission reduction, the unity of low-carbon production and consumption, the adaption of regional development policy and its resource endowments [2].

In the theory of low carbon economy, low carbon represents to build a new production and manufacturing methods which has less greenhouse gas emissions and don't based on fossil energy. Means to minimize reliance on the limited fossil energy and seek more clean energy, such as nuclear energy; solar energy, wind energy, bio energy, hydropower, geothermal energy, hydrogen energy and other renewable energy.

National innovation system theory. Innovation theory was first proposed by the famous economist Joseph Schumpeter, Then, Peter Drucker and other scholars have carried out a more in-depth exploration of the theory of innovation. The innovation process is not only a simple transportation knowledge and technology, but also through the combination of business process and learning process evolved, needing other organizations and institutions to cooperate and coordinate to produce more diverse and practical innovation. In 1987, based on the innovation theory, Freeman put forward the concept of national innovation system from the national level, and particular emphasized on the four elements of the government system, enterprises and their scientific and technological research and development, education and training, industrial structure. The focus of the study lies in technological innovation, more emphasis on the national technology innovation system [3]. Therefore, the innovation ability depends on the cooperation degree and the knowledge learning ability of each innovation subject in the system.

\section{Regional low carbon innovation system}

Connotation of regional low carbon innovation system. UK Carbon Trust Co., Ltd. in 2005 annual report pointed out that low carbon innovation in several ways, including product innovation, process innovation and organization innovation. The usually low carbon innovation is considered as a win-win initiative of not only effectively dealing with climate change, also providing the potential economic interests, and ultimately promotes the sustainable development [4]. Li Xianjiang believes that low carbon innovation refers to the product (service) technology, product (service) concept or business model on innovation and low carbon design [5]. On the basis of low carbon innovation, scholars have studied the innovation environment, and formed the basic concept of innovation system. Scientific research institution, University, enterprise and government in the main body of the national innovation system, it can more effectively enhance the innovation ability and efficiency, developing as a whole of the science and technology and social economy [6]. The subsystem of the 
national economic development is composed of the organization and mechanism with a variety of innovative behaviors and mutual influence and interaction in the process of innovation activities [7]. National low carbon technology innovation development is inseparable from the efficient co-ordination of the regional system. Regional low carbon innovation system is a system and policy network, which includes main factors, non subject elements and the relationship between the various elements of innovation [8]. Emphasize the interaction between the main bodies [9]. It contains the whole process of production, application, transformation and other related activities on low carbon knowledge and technology [10]. This paper argues that Regional low carbon innovation system is based on the innovation subject system of geographical division and connection as the boundary, including low-carbon technology and knowledge from the production to the performance of the whole process, emphasizing the interaction and cooperation between subjects, so as to effectively improve the regional low carbon economic, social and environmental performance and promote regional economic development and regional low carbon innovation cooperation. As shown in figure 1.

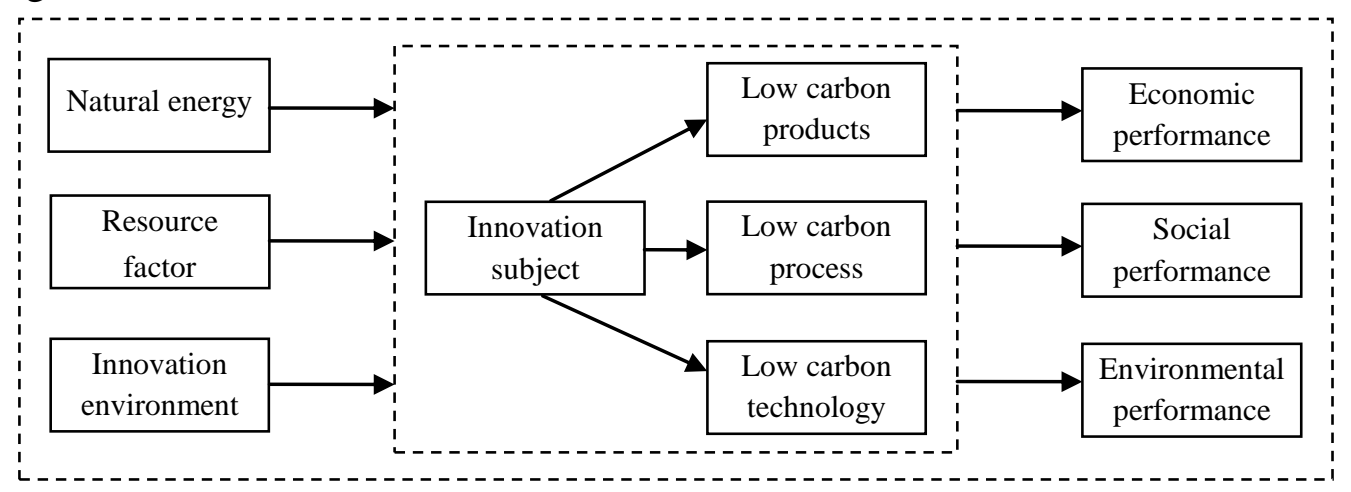

Figure.1 Conceptual model of regional low carbon innovation system

Basic elements. The system of regional low carbon innovation system is composed of many subject and structure elements. Research on regional innovation system is more common. Maillat put forward the regional innovation system has four basic elements: enterprises, institutions, environmental factors and the relevant policies and system that government has formulated [11]. Some domestic scholars also study the elements, that the regional innovation system is composed of enterprises, local governments, institutions of higher learning and research institutions, intermediary services within the region [12]. Some scholars believe that the scientific and technological resources under the market economy system, the continuous improvement of the enterprise, the government's new economic policies and relevant laws and regulations are the three major elements of regional innovation system [13]. According to scholars and OECD on regional innovation system research, and combined with Xiao Cheng $\mathrm{Lu}$ et al analysis of regional low carbon innovation system, proposed the regional low carbon innovation system mainly includes three elements: subject elements, function elements, the environmental elements. The innovation subjects include enterprises, universities, scientific research institutions, intermediary service organizations and local governments, which are related to low carbon innovation in the area. System functions include knowledge innovation, system innovation, technology innovation, management innovation. Innovative environment, including regional natural environment, institutional environment, market environment and social and cultural environment etc..

Innovative features. The main functions of regional low carbon innovation system in the operation including of knowledge innovation, technology innovation, system innovation, management innovation function. As shown in figure 2. 


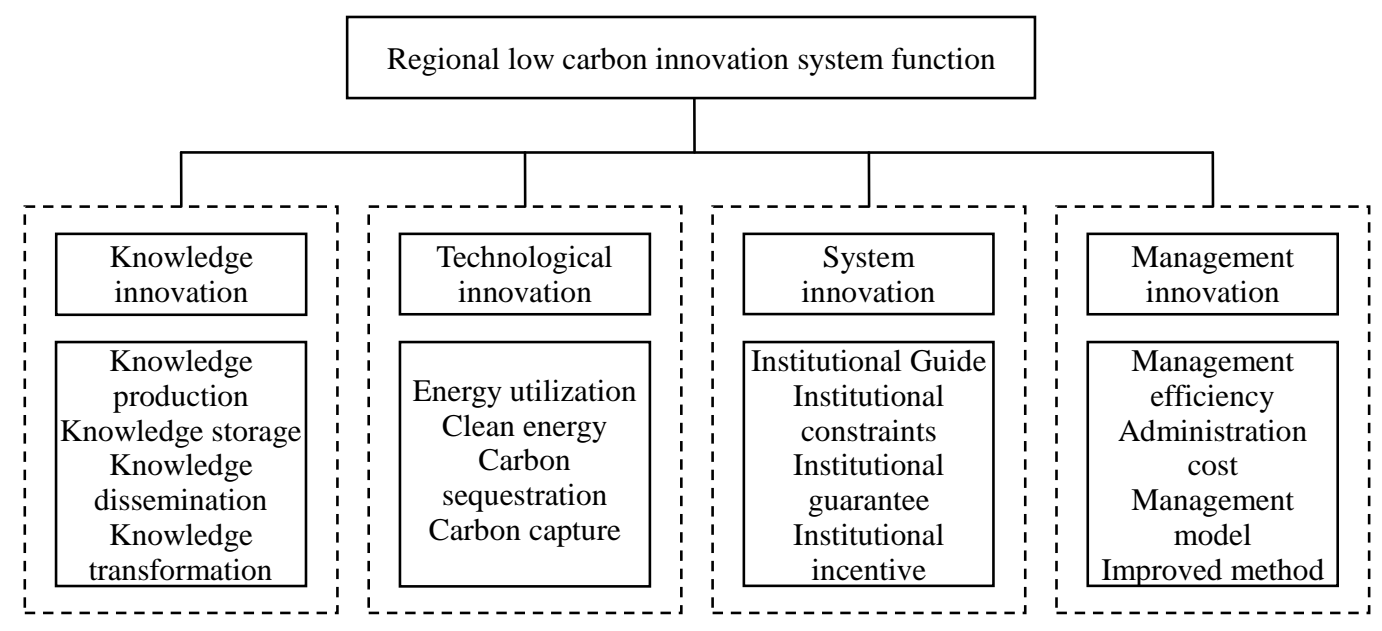

Figure.2 Regional low carbon innovation system functional elements

Knowledge innovation: The generation and application of knowledge determines the ability and prospect of low carbon innovation system. Technological innovation is the center [14].The knowledge stock directly affects the effect of low carbon innovation, and the speed and quality of knowledge dissemination are the key factors of the system operation. At the same time, the process of knowledge formation benefit is the ultimate goal of the regional low-carbon innovation system.

Technological innovation: The fundamental purpose of low carbon innovation system is to play its systematic role in low carbon innovation, so as to promote the development of low-carbon technology. Technology innovation of the system is the most important function of the system. To strengthen low carbon innovation mainly refers to reduce greenhouse gas emissions, improve energy efficiency and strength the management of waste emissions, involving the development of clean energy, carbon sequestration and carbon sequestration and other technological evolution.

System innovation: Regional system innovation is the foundation of low carbon innovation system. System innovation includes the creation of new system arrangement to deal with the complex and changeable system environment, put forward new regulations to constrain innovation main body of innovation activities, and through the improvement to the traditional system to adapt to the pace of global warming, which is in line with the policies and guidelines of the country to deal with environmental problems.

Management innovation: Regional low carbon innovation system needs management ideas, methods and related management tools to make it a stable development and needs management means to continuously optimize to adapt to the constantly updated technology and ability. At the same time, to guide the innovation subject of the regional to cooperate and develop in a certain mode.

Innovation resources. Regional low carbon innovation system resources are essential to the basic elements, including human resources, financial resources and information resources. As shown in figure 3.

Man is the most basic unit of the system. People are dynamic, but also be the source of inspiration for innovation. The efficient and smooth operation of the regional low carbon innovation system is dependent on the development of the talent and the management of the rational and reasonable guidance and the completion of a variety of labor. 


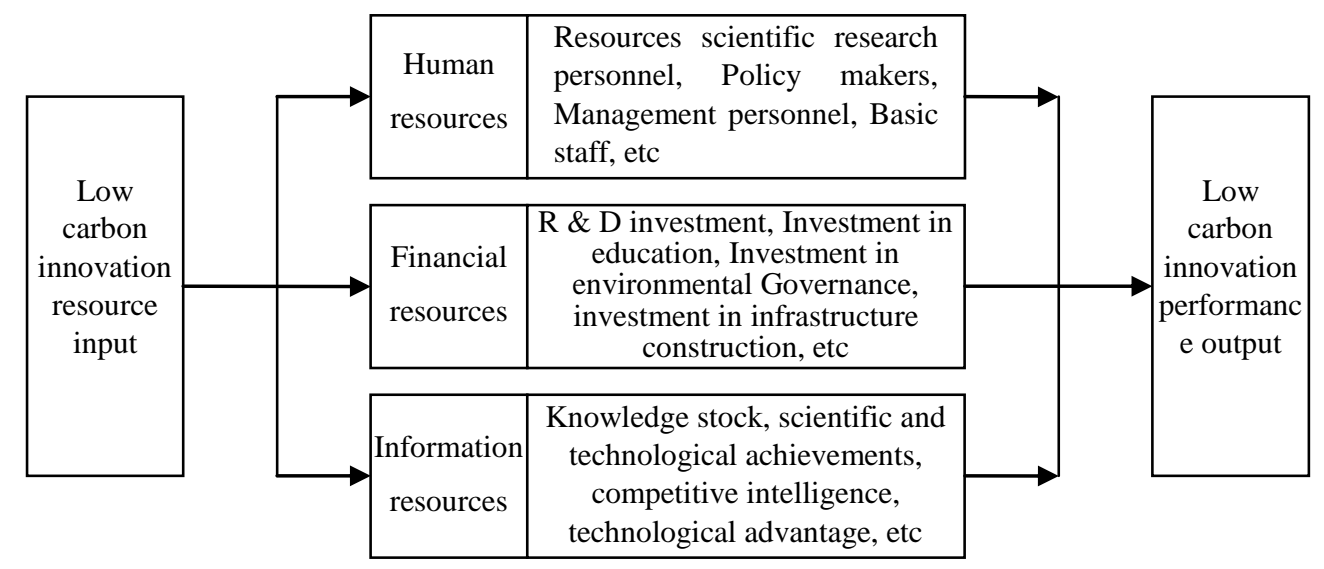

Figure.3 Innovation resources of regional low carbon innovation system

Financial resources refer to the country or region on the system of low carbon innovation funding scale, is the material base of scientific and technological research and development activities, but also the important guarantee for the transformation of low carbon innovation in the system. The difference of financial resources is related to the cultivation of low carbon talents, which directly affects the basic conditions of the infrastructure construction and the development of the region, and restricts the level of low carbon management.

Information resources refer to the internal data of the regional low carbon innovation system. The environment of system innovation process has a lot of uncertainty and external competition is more and more intense, to collect technology and information of external development based on the information which one has play an important role on low carbon innovation.

\section{Environment of regional low carbon innovation system}

The regional low carbon innovation system is influenced by the innovation environment, and it has the effect on the environment, Including the natural environment, system and policy environment, market environment and social and cultural environment. As shown in figure 4.

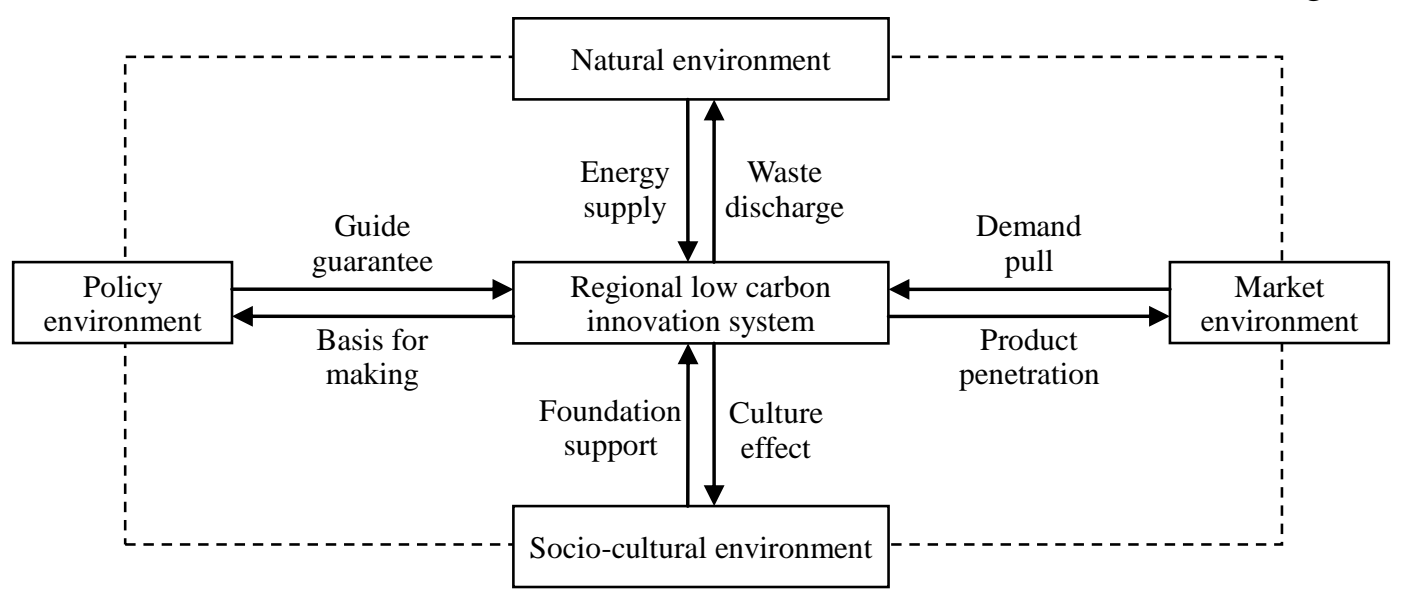

Figure.4 Innovation environment of regional low carbon innovation system

Natural environment. The natural environment is the basic condition of the regional low carbon innovation system, which involves the exploitation and utilization of resources, the pollution control and management. The advantages and disadvantages of the natural environment directly affect the overall innovation capability of the system, the speed and extent of the development of the system. 
System and policy environment. Regional low carbon innovation system is formed in the environment global response to climate warming, it is based on the overall low carbon planning and regional development and energy-saving emission reduction policies. System and policy environment can promote and guide the regional development, while the regional innovation system also caters to the national and regional development plan.

Market environment. Market drags innovation activities and innovative behavior of the regional low-carbon innovation system through the demand. Innovation subject must give full play to its role in the system of regional low carbon innovation, and constantly develop new products in order to have the breakthrough of low carbon innovation if it wants to gain recognition in the fierce competition and obtain more economic benefit and social benefit.

Social culture. Social and cultural environment, including people's behavior, thinking, understanding and recognition of low carbon innovation, but also includes the basic conditions of education level, talent stock and so on. Different ways of thinking and customs will lead to low carbon life attitude and cognition difference, so the regional low carbon innovation system should meet the needs of the society and people's psychological needs, and then expand low-carbon innovation activities according to the unique social and cultural characteristics.

\section{Benefits of regional low carbon innovation system}

Regional low carbon innovation system to achieve low carbon innovation function is by the innovation cycle and the use of "low carbon technology innovation - low carbon production and manufacturing - low carbon emissions and consumption - waste treatment and carbon sink" [15]. The effectiveness of input and output is the basis of the system operation. Reasonable input and high efficiency output is the goal of the system. Innovation system through the investment in human resources, financial resources and information resources, the main innovation division of labor and cooperation, technological innovation, product innovation, process innovation and organizational innovation, and ultimately produce economic benefit, social benefit and environmental system operation efficiency.

Regional low carbon innovation system is the main organization system to strengthen the development of regional economy with the focus on the economic output with less capital occupation and cost. The regional low carbon innovation system creates more economic wealth and regional economic improvement through the rational use of resources and integration of system elements.

Low carbon innovation output is conducive to strengthening the awareness of the masses in the region of low carbon consumption, thereby enhancing the popularity of the concept of low carbon, has an important role to social development of low carbon. Improvement of low carbon economic benefits will bring new low carbon industry total number of jobs, and Chinese industry has obvious export dependent feature and low carbon industrial products total export value in a large extent will affect the low carbon performance of innovation system.

Global environmental issues become increasingly prominent, low carbon model has become the world's main coping mode. Innovation system controls carbon dioxide emissions through the activities of low carbon, strengthens the fossil energy utilization efficiency, reduces the economic development dependence to energy and environment resources and improves air quality to achieve sustainable development. Establishing the following index system for the system performance evaluation can be based on the three major benefits of low carbon innovation system. See table 1 . 
Table 1 Index system.

\begin{tabular}{|c|c|c|}
\hline & First-grade index & Second-grade index \\
\hline \multirow{8}{*}{$\begin{array}{l}\text { The } \\
\text { performance } \\
\text { evaluation } \\
\text { index of } \\
\text { regional low } \\
\text { carbon } \\
\text { innovation } \\
\text { system }\end{array}$} & \multirow{3}{*}{ Economic benefit } & R\&D internal expenditure \\
\hline & & Scale of foreign direct investment FDI \\
\hline & & Total regional output value \\
\hline & \multirow{2}{*}{ Social benefit } & $\mathrm{R} \& \mathrm{D}$ personnel full time equivalent \\
\hline & & Effective invention patent number \\
\hline & \multirow{3}{*}{ Environmental system } & Investment in environmental infrastructure funds \\
\hline & & Carbon emission \\
\hline & & Energy consumption per unit GDP \\
\hline
\end{tabular}

In addition, the regional low-carbon innovation system is in line with the needs of the development of low carbon, and has good economic growth, social impact and environmental protection. These strengthened their low carbon products market competitiveness, and are advantageous in the fierce competition to occupy the advantageous position.

\section{Existing problems and suggestions}

At present, the theory of regional low carbon innovation system mainly concentrated in low carbon technology innovation, did not form a complete system of content and composition of mechanism and other relevant theory; and the research emphasis on low carbon innovation system is not perfect. China's awareness of the formation of low carbon innovation system is relatively late. The ability to innovate is uneven between regions [16]. China's investment in low carbon innovation and low carbon innovation system support is not enough, the investment in innovation of enterprises as the main body, market confidence and government low carbon policy formulation still need more comprehensive research and effective implementation.

Through the above analysis, the following suggestions are put forward on the development of China's regional low-carbon innovation system: (1) Strengthen the function realization and cooperation ability of innovation main body. Give full play to the innovation knowledge output capability of scientific research institutions and universities. Standardize the operation of technology diffusion intermediaries. Enterprises should introduce the knowledge and technology. The government effectively formulates policies to strengthen the information exchange and resource sharing between production and research [17]. (2) Increase or control the input of resources reasonably. System reasonably equipped with scientific research personnel to play the initiative and creativity of people. Invest financial resources according to the development needs of the region and to avoid the shortage or waste. Focus on information exchange and storage, and constantly improve the stock of knowledge and the region ability to absorb the knowledge. (3) Strengthen the construction of regional infrastructure. Rational and effective use of natural resources, strengthen the use of clean energy and improve energy efficiency to do a good job in carbon emissions; Improve the low carbon system in order to guide the operation of regional low carbon innovation system; develop healthy and orderly regional market environment [18], promote the production and circulation of low carbon products and improve the regional low carbon competitiveness; Strengthen social and cultural construction, improve the people's low carbon awareness and participation, and promote the effective development of regional low carbon innovation system. 


\section{Reference}

[1] DTI. Our energy future- creating a low carbon economy [M]. TSO, London, 2003.

[2] Y. Chen, W. T. Wang, Review on the evaluation of regional low carbon economy development, J. Chinese Journal of Population Resources and Environment. vol. 23, no. 4, (2013):124-128.

[3] C. Freeman, Technology Policy and Economic Performance: Lessons from Japan [M], London, Pinter Pub Ltd, 1987.

[4] Carbon Trust: Annual Report 2005/06[R]. London, 2006: Carbon Trust.

[5] X. J. Li, Research on the relationship between green entrepreneurial orientation, low carbon innovation and organizational performance in the service industry, J. Science of Science and Management of S. \& T., vol.33, no.8 (2012):36-43.

[6] Y. X. Lu, Rethinking of national innovation system, J. QiuShi, no.20 (2002):11 - 18.

[7] M. Balzat, H. Hanusch, Recent Trends in the Research on National Innovation Systems, J. Journal of Evolutionary Economics. vol. 2, no.14, (2004):197-210.

[8] L. C. Huang, Discussion on the research contents of regional innovation system, J. Science Research Management, vol. 21, no.2, (2000):44-48.

[9] P. Cooke, M. Uranga, G. Etxebarria, Regional Systems of Innovation: An Evolutionary Perspective, J. Environment \& Planning A, vol.30, no.9 (1998):1563-1584.

[10] J. C. Yi, G. Q. Xu, Y. H. Zhao, Study of government industry research integration based on regional low-carbon innovation system, J. Energy Procedia, no.5 (2011): 2494-2498.

[11] D. Doloxoreux. What We Should Know about Regional Systems of Innovation, J. Technology in Society, no.24(2002): 243-263.

[12] Z. J. Feng. Theory and policy of national innovation system, M, Beijing, Economic Science Press, 1999.

[13] Z. J. Hu, Jing SU. Put forward and development theory of regional innovation system, J. Forum on Science and Technology in China, no.6 (1999):19-23.

[14] H. Meng. Cluster regional innovation system based on industrial clusters, J. Tian Fu New Idea, no.2 (2004): 54-56.

[15] X. C. Lu. The construction of regional low carbon innovation system--Based on the perspe -ctive of Technology Foresight, J. Science technology and Dialectics, vol.25, no.6(2008): 91-101.

[16] X. D. Zhan, B. L. Wang. The effect of regional knowledge management on regional innovation capability, J. Chinese Journal of Management, vol.12, no.5(2015):710-718.

[17] X. D. Li, J. T. Chen. Research on the path of FDI to the evolution of regional innovation system -- Based on the analysis of structural equation model, J. Science of Science and Management of S. \& T., vol.35, no.8(2014):39-48.

[18] B. Z. Li, S. Zhou. Research on the relationship between the innovation behavior of scientific research institutes and the performance of regional innovation, J. Science of Science and Management of S. \& T., vol. 36,no.1(2015):76-87. 